\title{
An Economic Analysis of Foreign Direct Investment in Retail Sector in India
}

\author{
Girish Garg \\ E mail ID: gggarg22@gmail.com
}

\section{INTRODUCTION}

Retailing is the interface between the producers and individual consumers buying for personal consumption or use. As such retailing is the last link that connects consumers or customers with the manufactures and distribution chain. Whether it is manufactures, distributors, wholesalers, if they sale the goods and service directly to buyers then they are called retailers and their trading activity come under retailing.

Retailing in India is one of the pillars of its economy and accounts for 14 to 15 percent of its GDP. The Indian retail market is estimated to be US\$ 450 billion and one of the top five retail markets in the world by economic value. India is one of the fastest growing retail markets in the world, with 1.2 billion people.

India's retailing industry is essentially owner manned small shops. In 2010, larger format convenience stores and supermarkets accounted for about 4 percent of the industry, and these were present only in large urban centres. India's retail and logistics industry employs about 40 million Indians (3.3\% of Indian population).

Until 2011, Indian central government denied foreign direct investment (FDI) in multi-brand retail, forbidding foreign groups from any ownership in supermarkets, convenience stores or any retail outlets. Even single-brand retail was limited to $51 \%$ ownership and a bureaucratic process.

In November 2011, India's central government announced retail reforms for both multi-brand stores and single-brand stores. These market reforms paved the way for retail innovation and competition with multi-brand retailers such as WalMart, Carrefour and Tesco, as well single brand majors such as IKEA, Nike, and Apple. The announcement sparked intense activism, both in opposition and in support of the reforms. In December 2011, under pressure from the opposition, Indian government placed the retail reforms on hold till it reaches a consensus.

In January 2012, India approved reforms for single-brand stores welcoming anyone in the world to innovate in Indian retail market with $100 \%$ ownership, but imposed the requirement that the single brand retailer source 30 percent of its goods from India. Indian government continues the hold on retail reforms for multi-brand stores.

In June 2012, IKEA announced it has applied for permission to invest \$1.9 billion in India and set up 25 retail stores. Fitch believes that the 30 percent requirement is likely to significantly delay if not prevent most single brand majors from Europe, USA and Japan from opening stores and creating associated jobs in India.

On 14 September 2012, the government of India announced the opening of FDI in multi-brand retail, subject to approvals by individual states. This decision has been welcomed by economists and the markets, however has caused protests and an upheaval in India's central government's political coalition structure. On 20 September 2012, the Government of India formally notified the FDI reforms for single and multi-brand retail, thereby making it effective under Indian law.

On 7 December 2012, the Federal Government of India allowed 51\% FDI in multi-brand retail in India. The Feds managed to get the approval of multi-brand retail in the parliament despite heavy uproar from the opposition. Some states will allow foreign supermarkets like Wal-Mart, Tesco and Carrefour to open while other states will not.

\section{TYPES OF RETAILING IN INDIA}

Single Brand- Single brand implies that foreign companies would be allowed to sell goods sold a retail store with foreign investment can only sell one brand. For example, if Adidas were to obtain permission to retail its flagship brand in India, those retail outlets could only sell products under the Adidas brand and not the Reebok brand, for which separate permission is required. If granted permission, Adidas could sell products under the Reebok brand in separate outlets.

Multi Brand- FDI in Multi Brand retail implies that a retail store with a foreign investment can sell multiple brands under one roof. Opening up FDI in multi-brand retail will mean that global retailers including Wal-Mart, Carrefour and Tesco can open stores offering a range of household items and grocery directly to consumers in the same way.

The approval for single and multi brand includes a set of riders for the foreign investors, aimed at ensuring that the foreign investment makes a genuine contribution to the development of Indian infrastructure and logistics, at the same time 
facilitating integration of small retailers into the upgraded value chain. While the minimum capital requirement of US\$ 100 million is unlikely to be an issue for the large foreign players vying to enter India in the supermarket/ hypermarket segment, it could make it difficult for foreign investors planning to enter specialty formats such as music, mobile, electronics goods, among others, as these formats require relatively lower investments. Further, the approval requirements from State Governments could limit the cities that FDI backed retailers can operate in. The current opposition raised by a number of political parties, if persists, may pose a major roadblock in the entry of the foreign retailers in India. Besides restricting the number of cities these retailers can operate in, it could also lead to problems in creating supply chain efficiency.

Table- 1: A Comparison of Norms under Single-brand and Multi-brand Retail in India

\begin{tabular}{|c|c|c|}
\hline Parameters & Multi-brand & Single-brand \\
\hline $\begin{array}{l}\text { Ownership/ } \\
\text { Requirement }\end{array}$ & $\begin{array}{l}\text { Minimum investment of US\$ } \\
\text { 100million by the foreign } \\
\text { investor }\end{array}$ & $\begin{array}{l}\text { The foreign investor should be } \\
\text { an owner of the brand }\end{array}$ \\
\hline $\begin{array}{l}\text { Investment towards back-end } \\
\text { infrastructure }\end{array}$ & $\begin{array}{l}\text { At least } 50 \% \text { of the investment } \\
\text { by the foreign company to be } \\
\text { in back-end infrastructure }\end{array}$ & No condition \\
\hline Location of stores & $\begin{array}{l}\text { Stores to be restricted to cities } \\
\text { with a population of one } \\
\text { million or more ( } 53 \text { cities as } \\
\text { per } 2011 \quad \text { Census); given } \\
\text { constraints around real estate, } \\
\text { retailers are allowed to set up } \\
\text { stores within } 10 \mathrm{~km} \text { of such } \\
\text { cities }\end{array}$ & No Condition \\
\hline Sourcing & $\begin{array}{l}\text { At least } 30 \% \text { of manufactured } \\
\text { items procured should } \\
\text { through domestic small } \\
\text { medium enterprises (SMEs) }\end{array}$ & \begin{tabular}{llr} 
In respect of & \multicolumn{2}{c}{ proposals } \\
involving FDI & beyond & $51 \%$, \\
$30 \%$ & sourcing & would \\
mandatorily have to be done & \\
from domestic SMEs & and \\
cottage industries artisans and & \\
craftsmen & & \\
\end{tabular} \\
\hline Sales & No Condition & $\begin{array}{l}\text { Products to be sold should be } \\
\text { of a which are branded during } \\
\text { manufacturing) only; sold } \\
\text { under the same brand name } \\
\text { internationally }\end{array}$ \\
\hline $\begin{array}{l}\text { Approval of } \\
\text { Governments required }\end{array}$ & $\begin{array}{l}\text { While the proposals on FDI } \\
\text { will be sanctioned by the } \\
\text { Centre, approvals from } \\
\text { State Government would be } \\
\text { required }\end{array}$ & $\begin{array}{l}\text { While the proposals on FDI } \\
\text { will be sanctioned by the } \\
\text { Centre, approvals from each } \\
\text { State Government would be } \\
\text { required }\end{array}$ \\
\hline
\end{tabular}




\section{TYPE OF RETAIL MARKET IN INDIA}

Organized retailing: - Organized retailing refers to trading activities undertaken by licensed retailers, that is, those who are registered for sales tax, income tax, etc. These include the corporate-backed hypermarkets and retail chains, and also the privately owned large retail businesses.

Unorganized retailing: - Unorganized retailing, on the other hand, refers to the traditional formats of low-cost retailing, for example, the local kirana shops, owner manned general stores, paan/beedi shops, convenience stores, hand cart and pavement vendors, etc.

India's retail sector is wearing new clothes and with a three-year compounded annual growth rate of 46.64 per cent retail is the fastest growing sector in the Indian economy. Traditional markets are making way for new formats such as departmental stores, hypermarkets, supermarkets and specialty stores. Western-style malls have begun appearing in metros and second-rung cities alike, introducing the Indian consumer to an unparalleled shopping experience. The Indian retail sector is highly fragmented with 97 per cent of its business being run by the unorganized retailers like the traditional family run stores and corner stores. The organized retail however is at a very nascent stage though attempts are being made to increase its proportion to 9-10 per cent by the year 2010 bringing in a huge opportunity for prospective new players. The sector is the largest source of employment after agriculture, and has deep penetration into rural India generating more than 10 per cent of India's GDP.

The last few years witnessed immense growth by retail sector, the key drivers being changing consumer profile and demographics, increase in the number of international brands available in the Indian market, economic implications of the Government increasing urbanization, credit availability, improvement in the infrastructure, increasing investments in technology and real estate building a world class shopping environment for the consumers. In order to keep pace with the increasing demand, there has been a hectic activity in terms of entry of international labels, expansion plans, and focus on technology, operations and processes.

This has lead to more complex relationships involving suppliers, third party distributors and retailers, which can be dealt with the help of an efficient supply chain. A proper supply chain will help meet the competition head-on, manage stock availability; supplier relations, new value added services, cost cutting and most importantly reduce the wastage levels in fresh produce. Large Indian players like Reliance, Ambanis, K Rahejas, Bharti AirTel, ITC and many others are making significant investments in this sector leading to emergence of big retailers who can bargain with suppliers to reap economies of scale. Hence, discounting is becoming an accepted practice. Proper infrastructure is a pre-requisite in retailing, which would help to modernize India and facilitate rapid economic growth. This would help in efficient delivery of goods and value-added services to the consumer making a higher contribution to the GDP.

International retailers see India as the last retailing frontier left as the China's retail sector is becoming saturated. However, the Indian Government restrictions on the FDI are creating ripples among the international players like Wal-Mart, Tesco and many other retail giants struggling to enter Indian markets. As of now the

Government has allowed only 51 per cent FDI in the sector to 'one-brand' shops like Nike, Reebok etc. However, other international players are taking alternative routes to enter the Indian retail market indirectly via strategic licensing agreement, franchisee agreement and cash and carry wholesale trading (since 100 per cent FDI is allowed in wholesale trading).

The central government commissioned the Indian council for research on international economics relation (ICRIER) to examine the impact of organised retail an unorganised retail. The standing committee on commerce also tabled a report on foreign and domestic investment in retail sector in May 2009 while the department of industrial policy and promotion (DIPP) released a discussion paper examining FDI in multi - brand retail in July 2010. Other experts have also made argument -both in support of, and in opposition to the move to permit FDI in retail sales. The table below summarise some of these arguments from the perspective of various stakeholders as collated from the above report examining the issue.

Table2: a comparison of supporting and opposing argument among various stakeholders

\begin{tabular}{|l|c|c|}
\hline Stakeholders & Supporting argument (source) & Opposing argument (source) \\
\hline $\begin{array}{l}\text { Unorganised } \\
\text { retail }\end{array}$ & $\begin{array}{c}\text { No evidence of impact on job } \\
\text { losses (ICRIER) }\end{array}$ \\
$\begin{array}{c}\text { retailers in the vicinity of } \\
\text { organised rate of closure of }\end{array}$ & \begin{tabular}{c} 
volume of business and profit saw their \\
\hline
\end{tabular}
\end{tabular}




\begin{tabular}{|c|c|c|}
\hline & $\begin{array}{l}\text { unorganised } \begin{array}{l}\text { retail } \\
(4.2 \%) \quad \text { is }\end{array} \\
\text { international } \\
\text { (ICRIER) } \\
\text { than } \\
\text { Ehina standard } \\
\text { show that and modern retail can coexist } \\
\text { and grow } \quad \text { (Reardon } \\
\text { Gulati) } \\
\text { keen to remain in operation } \\
\text { even after } \quad \text { emergence } \\
\text { organised retail (ICRIER) }\end{array}$ & $\begin{array}{l}\text { decline but this effect weakens } \\
\text { over time (ICRIER) } \\
\begin{array}{l}\text { Other studies have } \\
\text { that traditional estimated } \\
\text { vegetable retailers experienced a }\end{array} \\
20-30 \% \text { decline in income with } \\
\text { the presence of } \\
\text { (SINGH) } \\
\text { There pupermarket } \\
\text { employment loss in the value } \\
\text { chain. A supermarket } \\
\text { create fewer jobs for the volume } \\
\text { of produce handled (SINGH) } \\
\square \text { Unemployment to increase as a } \\
\text { result of retailers } \\
\text { product banding (selling good in } \\
\text { combination and bargain) } \\
\text { predatory pricing (STANDING } \\
\text { COMMITTEE) }\end{array}$ \\
\hline Farmers & 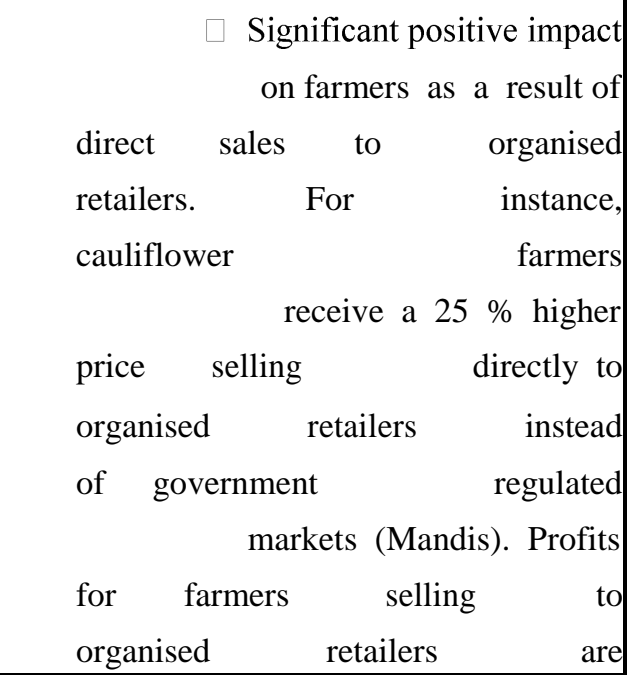 & 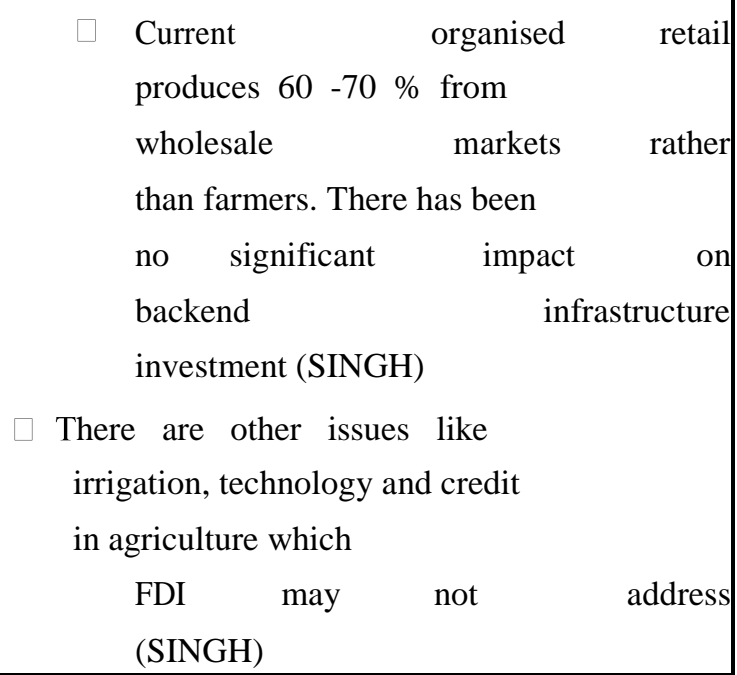 \\
\hline
\end{tabular}




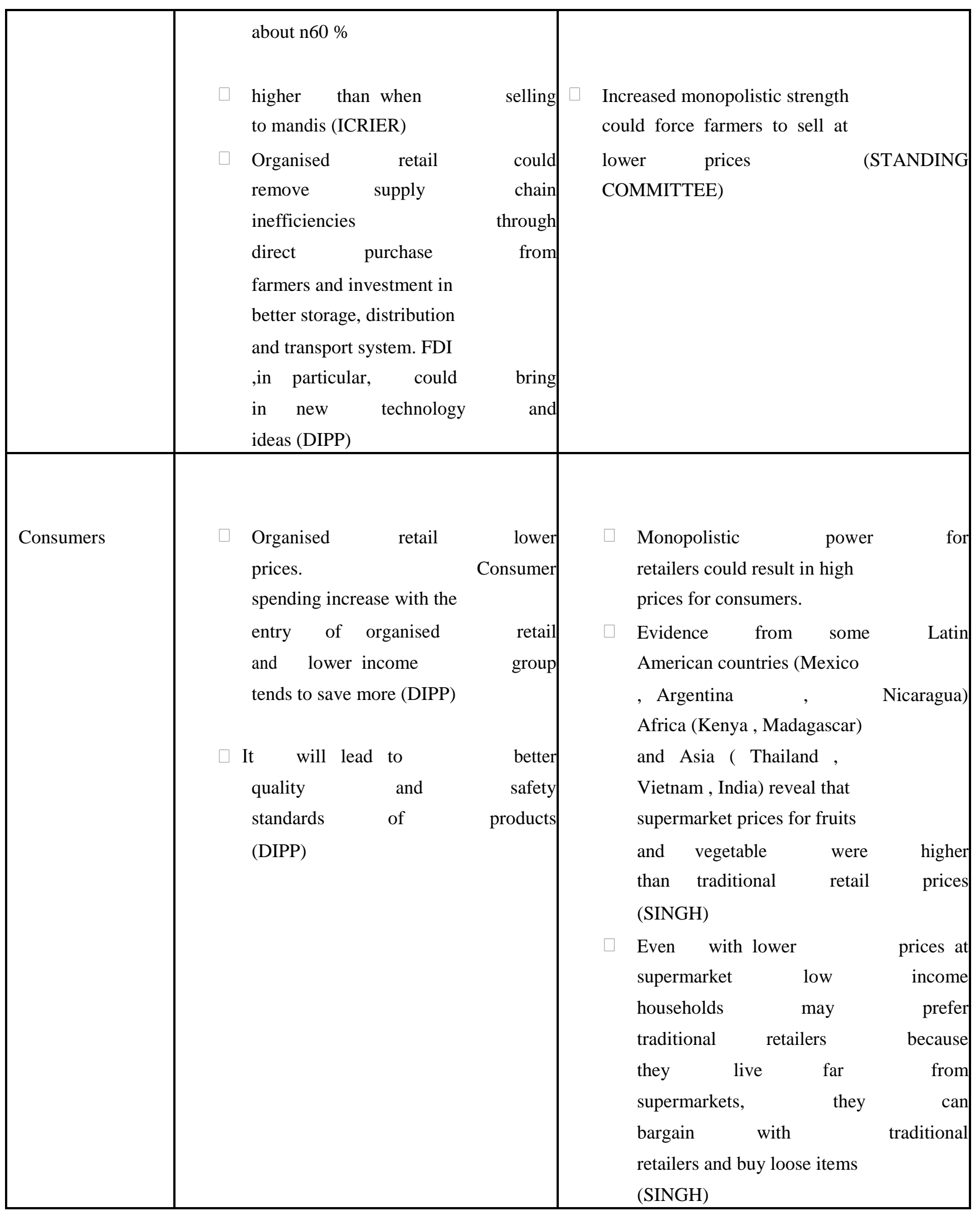




\section{OPPORTUNITIES AND THREATS OF FDI IN RETAIL IN INDIA}

Market liberalization, a growing middle-class, and increasingly assertive consumers are sowing the seeds for a retail transformation that will bring more Indian and multinational players on the scene. India is tipped as the second largest retail market after China, and the total size of the Indian retail industry is expected to touch the $\$ 300$ billion mark in the next five years from the current \$200 billion. But the recent debate has cantered on the issue of whether FDI in retail were conducted to analyze the impact of FDI in retail sector in various segments of the economy. According to a policy paper prepared by the Department of Industrial Policy and Promotion (DIPP, 2010), FDI in retail must result in backward linkages of production and manufacturing and spur domestic retailing as well as exports. According to the World Bank, opening the retail sector to FDI would be beneficial for India in terms of price and availability of products. While FDI in multi-brand retail has been opposed by several in the past citing fears of loss of employment, adverse impact on traditional retail and rise in imports from cheaper sources like China, adherents of the same indicate increased transfer of technology, enhanced supply chain efficiencies and increased employment opportunities as the perceived benefits.

Key Perceived Opportunities The following may be regarded as major perceived benefits of allowing FDI in retail in India.

1. Capital Infusion- This would provide an opportunity for cash-deficient domestic retailers to bridge the gap between capital required and raised. In fact FDI is one of the major sources of investments for a developing country like India wherein it expects investments from Multinational companies to improve the countries growth rate, create jobs, share their expertise, back-end infrastructure and research and development in the host country.

2. Boost Healthy Competition and check inflation- Supporters of FDI argue that entry of the many multi-national corporations will obviously promise intensive competition between the different companies offering their brands in a particular product market and this will result in availability of many varieties, reduced prices, and convenient distribution of the marketing offers.

3. Improvement in Supply Chain- Improvement of supply chain/ distribution efficiencies, coupled with capacity building and introduction of modern technology will help arrest wastages (in the present situation improper storage facilities and lack of investment in logistics have been creating inefficiencies in food supply chain, leading to significant wastages).

4. Improvement in Customer Satisfaction- Consumers in the organized retail will have the opportunity to choose between a numbers of internationally famous brands with pleasant shopping environment, huge space for product display, maintenance of hygiene and better customer care. There is a large segment of the population which feels that there is a difference in the quality of the products sold to foreign retailers and the same products -stoppage of different products. If the market is opened, then the pricing could also change and the monopoly of certain domestic Indian companies will be challenged.

5. Improved technology and logistics- Improved technology in the sphere of processing, grading, handling and packaging of goods and further technical developments in areas like electronic weighing, billing, barcode scanning etc. could be a direct consequence of foreign companies opening retail shops in India,. Further, transportation facilities can get a boost, in the form of increased number of refrigerated vans and pre-cooling chambers which can help bring down wastage of goods.

6. Benefits for the Farmers- Presumably, with the onset of multi-brand retail, the food and packaging industry will also get an impetus. Though India is the second largest producer of fruits and vegetables, it has a very limited integrated cold-chain infrastructure. Lack of adequate storage facilities causes heavy losses to farmers, in terms of wastage in quality and quantity of produce in general, and of fruits and vegetables in particular. With liberalization, there could be a complete overhaul of the currently fragmented supply chain infrastructure. Extensive backward integration by multinational retailers, coupled with their technical and operational expertise, can hopefully remedy such ventures with retailers which helps (I) to cut down intermediaries ; (ii) give better prices to farmers, and (iii) provide stability and economics of scale which will benefit, in the ultimate analysis, both the farmers and consumers.

7. Creation of More And Better Employment Opportunities- The entry of foreign companies into Indian Retailing will not only create many employment opportunities but, will also ensure quality in them. This helps the Indian human resource to find better quality jobs and to improve their standard of living and life styles on par with that of the citizens of developed nations. 
Key Potential Threats Critics of FDI feel that liberalization would jeopardize the unorganized retail sector and would adversely affect the small retailers, farmers and consumers and give rise to monopolies of large corporate houses which can adversely affect the pricing and availability of goods. They also contend that the retail sector in India is one of the major employment providers and permitting FDI in this sector can displace the unorganized retailers leading to loss of livelihood. The major threats to the domestic retailers in India are specified below:

1. Domination of Organized Retailers- FDI in single-brand retail will strengthen organized retail in the country. These organized retailers will tend to dominate the entire consumer market. It would lead to unfair competition and ultimately result in large-scale exit of domestic retailers, especially the small family managed.

2. Create Unemployment- Retail in India has tremendous growth potential and it is the second largest employer in India. Any changes by bringing major foreign retailers who will be directly procuring from the main supplier will not only create unemployment on the front end retail but also the middleman who have been working in this industry will be thrown out of their jobs.

3. Loss of Self Competitive Strength- The Indian retail sector, particularly organized retail, is still under-developed and in a nascent stage and that, therefore the companies may not be able to compete with big global giants. If the existing firms collaborate with the global biggies they might have to give up at the global front by losing their self competitive strength.

4. Indirectly Leads to Increase in Real Estate Cost- It is obvious that the foreign companies which enter into India to open up their malls and stores will certainly look for places in the heart of the cities. There shall be a war for place, initiated among such companies. It will result in increase in the cost of real estate in the cities that will eventually affect the interest of the ordinary people who desire to own their houses within the limit of the cities.

5. Distortion of Culture: Though FDI in Indian retail will indirectly or directly contribute for the enhancement of Tourism, Hospitality and few other Industries, the culture of the people in India will slowly be changed. The youth will easily imbibe certain negative aspects of foreign culture and lifestyles and develop inappropriate consumption pattern, not suited to our cultural environment.

\section{PORTER'S FIVE FORCE MODEL}

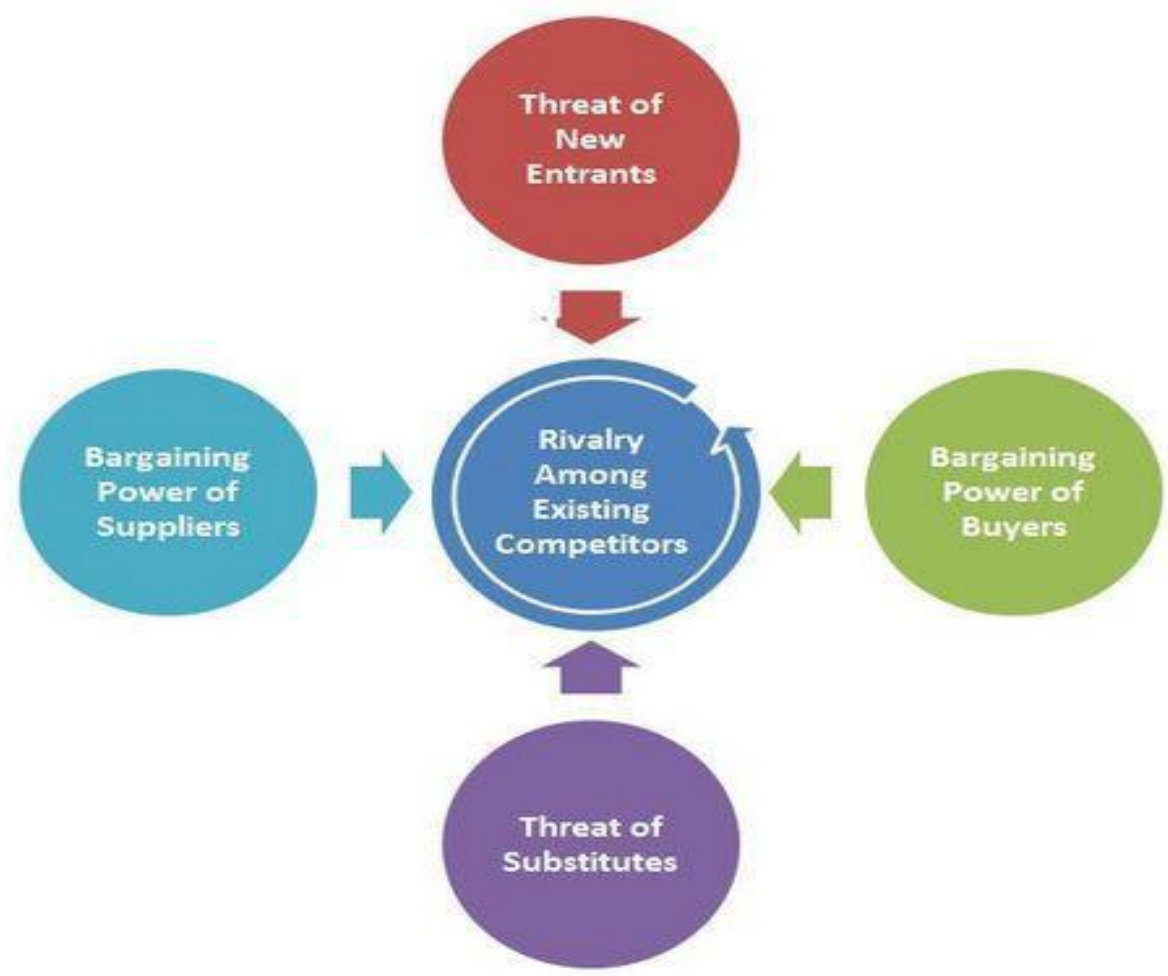

1. Threat of New Entrants: 
One trend that started over a decade before has been a decreasing number of independent retailers. While the barriers to start up a new store are not impossible to overcome, the ability to establish favourable supply contracts, Leases and be competitive is becoming virtually impossible. There vertical Structure and centralized buying gives chain stores a competitive advantage Over independent retailers. 95\% of the market is made up of small, uncomputerised

Family run stores. Now there are finally signs that the Indian Government dropping its traditional protectionist stance and opening up its Retail market to greater overseas investment. It has already allowed 51\% Ownership in single-brand goods leading to entry of McDonalds, Marks \& Spencer, Body Shop and IKEA and with proposal of raising the ownership to $100 \%$ will attract more foreign retailers. Also with allowing investment by foreign retailers in multi-brand retailing in a phased manner will lead to more Inflow of foreign investors in Indian retail sector. On the whole threat from New entrants in retail industry are high.

\section{Power of Suppliers:}

Historically, retailers have tried to exploit relationships with supplier. A great Example was in the 1970s, when Sears sought to dominate the household Appliance market. Sears set very high standards for quality; suppliers that did into meet these standards were dropped from the Sears line. This could also be seen in case of Wal-Mart that places strict control on its suppliers. A Contract with a big retailer like Wal-Mart can make or break a small supplier. In Retail industry suppliers tend to have very little power.

\section{Power of Buyers:}

Individually, consumers have very little bargaining power with retail stores. It is very difficult to bargain with the clerk at Big Bazaar for better price on Grapes. But as a whole if customers demand high-quality products at bargain Prices, it helps keep retailers honest. Taking this from Porter's side of the coin We can say customers have comparatively high bargaining power in Unorganized sector than in organized sector. As the customer will demand Products from organized units he will be more focused towards quality aspect.

\section{Availability of Substitutes:}

The tendency in retail is not to specialize in one good or service, but to deal in Wide range of products and services. This means what one store offers is Likely to be same as that offered by another store. Thus threat from Substitutes is high.

\section{Competitive Rivalry:}

Retailers always face stiff competition and must fight with each other for Market share and also with unorganized sector. More recently, they have tried To reduce cut throat pricing competition by offering frequent flier points, memberships and other special services to try and gain the customer's loyalty. Thus retailers give each other stiff but healthy competition which is evident from their aggressive marketing strategies and segment policies.

\section{SWOT ANALYSIS OF RETAIL SECTOR}

\section{Strengths:}

Major contribution to GDP: the retail sector in India is hovering around $15-25 \%$ of GDP as compared to around $16 \%$ in USA.

High Growth Rate: the retail sector in India enjoys an extremely high Growth rate of approximately $46 \%$.

High Potential: since the organised portion of retail sector is only 4-5\%, Thereby creating lot of potential for future players.

High Employment Generator: the retail sector employs 7\% of work Force in India, which is right now limited to unorganised sector only. Once the Reforms get implemented this percentage is likely to increase substantially.

\section{Weaknesses (limitation):}

Lack of Competitors: AT Kearney's study on global retailing trends Found that India is least competitive as well as least saturated markets of the World.

Highly Unorganised: The unorganised portion of retail sector is only $95 \%$ compared to US, which is only 15 $\%$.

Low Productivity: McKinney study claims retail productivity in India is Very low as compared to its international peers. 
Shortage of Talented Professionals: the retail trade business in India is not considered as reputed profession and is mostly carried out by the Family members (self-employment and captive business). Such people are not academically and professionally qualified.

No Industry status, hence creating financial issues for Retailers: The retail sector in India does not enjoy industry status in India. Thereby making difficult for retailers to raise funds.

\section{Opportunities (benefits):}

There will be more organization in the sector: Organized retail will need more workers. According to findings of KPMG, in China, the Employment in both retail and wholesale trade increased from 4\% in 1992 to About $7 \%$ in 2001, post reforms and innovative competition in retail sector in That country.

Healthy Competition will be boosted and there will be a Check on the prices (inflation): Retail giants such as Wal-Mart, Carrefour, Tesco, Target and other global retail companies already have Operations in other countries for over 30 years. Until now, they have not at all become monopolies rather they have managed to keep a check on the food Inflation through their healthy competitive practices.

Create transparency in the system: the intermediaries operating as per mandi norms do not have transparency in their pricing. According to some of the reports, an average Indian farmer realises only one-third of the Price, which the final consumer pays.

Intermediaries and mandi system will be evicted, hence directly benefiting the farmers and producers: the prices of Commodities will automatically be checked. For example, according to Business Standard, Wal-Mart has introduced -Direct Farm Projectll at Haide Nagar in Punjab, where 110 farmers have been connected with Bharti Wal-Mart for sourcing fresh vegetables directly.

Quality Control and Control over Leakage and Wastage Due to organisation of the sector, $40 \%$ of the production does not reach the Ultimate consumer. According to the news in Times of India, $42 \%$ of the Children below the age group of 5 are malnourished and Prime Minister Dr. Manmohan Singh has termed it as national shame. Food often gets rot in Farm, in transit and in state-run warehouses. Cost conscious and highly Competitive retailers will try to avoid these wastages and losses and it will be Their endeavour to make quality products available at lowest prices, hence Making food available to weakest and poorest segment of Indian society.

Heavy flow of capital will help in building up the Infrastructure for the growing population: India is already Operating in budgetary deficit. Neither the government of India nor domestic Investors are capable of satisfying the growing needs (school, hospitals, Transport etc.) Of the ever growing Indian population. Hence foreign capital Inflow will enable us to create a heavy capital base.

There will be sustainable development and many other Economic issues will be focussed upon: much Indian small shop Owners employ workers, who are not under any contract and also under aged Workers giving rise to child-labour. It also boosts corruption and black money.

4. Threats:

Current Independent Stores will be compelled to close: This will lead to massive job loss as most of the operations in big stores like Wal-Mart is highly automated requiring fewer work forces.

Big players can knock-out competition: they can afford to lower Prices in initial stages become monopoly and then raise prise later.

India does not need foreign retailers: as they can satisfy the Whole domestic demand.

Remember East India Company it entered India as trader and then took over politically.

The government hasn't able to build consensus.

In view of the above analysis, if we try to balance opportunities and prospects attached to the given economic reforms, it will definitely cause good to Indian Economy and consequently to public at large, if once implemented. Thus the period for which we delay these reforms will be loss for government only, since majority of the public is in favour of reforms. All the above mentioned drawbacks are mostly politically created. With the implementation of this policy all stakeholders will benefit whether it is consumer through quality products at 
low price, farmers through more Transparency in trading or Indian corporate with $49 \%$ profit share remaining with Indian companies only.

\section{REFERENCES}

1. Department of Industrial Policy and Promotion, 2010. "Foreign Direct Investment (FDI) in Multi-Brand Retail Trading," Discussion paper. Available at http://www.dipp.nic.in

2. Impact of organised retailing on the unorganised sector (ICRIER September 2008)

3. Foreign and domestic investment in retail sector, standing committee on commerce, may 13, 2009

4. "FDI in Retail: - misplaced expectations and Half-truths", Sukhpal Singh, Economic and political Weekly December 17, 2011

5. "Rise in supermarket and their development implication" IFPRI Discussion Paper, Thomas Reardon and Ashok Gulati, February 2008

6. "Discussion paper on FDI in multi-brand Retail Trading", department of Industrial Policy and Promotion July 6, 2010 